\title{
POTENTIALS OF MIXED CULTURES OF BACTERIA IN THE BIODEGRADATION OF CRUDE OIL
}

\author{
Tomilayo R. B., Sani A. and *Sule I.O. \\ Department of Microbiology, University of Ilorin, Ilorin, Kwara State, Nigeria. \\ *Corresponding author's e-mail: suleism@gmail.com; Tel.: +2348056663764 \\ (Received: $29^{\text {th }}$ April, 2018; Accepted: $2^{\text {nd }}$ September, 2019)
}

\section{ABSTRACT}

\begin{abstract}
This study aimed at exploring the potentials of mixed cultures of bacteria isolated from crude oil polluted sites for the biodegradation of crude oil. Mixed cultures of five bacterial isolates: Psendomonas aeruginosa, $P$. putida, P. fluorescens, Bacillus subtilis and Micrococcus luteus were used for the crude oil biodegradation study. The degrading ability of the mixed cultures were assessed for duration of 28 days on a shaker at $300 \mathrm{rpm}$ and at ambient temperatures $\left(28 \pm 2{ }^{\circ} \mathrm{C}\right)$ in a mineral salt broth amended with $1 \%$ crude oil. Parameters used to assess the degradative abilities were $\mathrm{pH}$, bacterial load, and residual crude oil contents. The result showed a significant increase in the bacterial count as the biodegradative study progressed while the $\mathrm{pH}$ and residual crude oil content decreased. The consortium of $P$. aeruginosa, $P$. putida, P. fluorescens, B. subtilis and $M$. luteus (CB1) was able to achieve reduction of crude oil to $92.4 \%$ followed by $P$. aeruginosa, $P$. putida, and $P$. fluorescens (CB2) with reduction of $89.5 \%$ in 28 days of biodegradative study. It is concluded from this study that the consortium CB1 were effective crude oil degraders. Thus, they are recommended for use in the bioremediation of polluted soils.
\end{abstract}

Key words: Polluted soils, Crude oil, Consortia, Bacteria, Biodegradation.

\section{INTRODUCTION}

Nigeria, a major producer of petroleum, is enmeshed in serious environmental pollution problems arising from petroleum exploration, exploitation, transportation and consumption coupled with inadequate maintenance of oil pipelines resulting in seepages and ruptures (Okerentugba and Ezenronye, 2003; Akpotor, 2019). This problem has become compounded in recent years by increasing sabotage and vandalization of pipelines by restive oil communities particularly in the Niger Delta area of the country (Ujowundu et al., 2011; Ohanmu et al., 2019).

Microbial remediation of hydrocarboncontaminated site is performed with the help of a diverse group of microorganisms, particularly the indigenous soil bacteria. These microorganisms can degrade a broad array of target constituents present in oily sludge (Mishra et al., 2001). A large number of Pseudomonas spp. capable of degrading complex hydrocarbons have been isolated from soil and aquifers (Johnson et al., 1996). It is the consortium of microorganisms rather than a single organism that is more appropriate to degrade a mixture of hydrocarbons like crude oil, kerosene, or waste water from refinery or petrochemical industries. Previous studies of complex hydrocarbon degradation by mixed and pure cultures presented evidence that there are interactions between complex hydrocarbons and the consortia (Bauer and Capone, 1988).

This research is justified due to the fact that pollution of aquatic and soil environments by crude oil is unabating and there is need to isolate and identify bacterial consortia capable of degrading crude oil. The objectives of this study were to isolate bacterial species from crude oil contaminated soils; identify the bacterial isolates; and determine the effectiveness of the bacterial consortia in effecting crude oil biodegradation.

\section{MATERIALS AND METHODS}

\section{Isolation and Purification of Hydrocarbon} Utilizing Bacteria from Crude Oil

\section{Contaminated Soils}

Crude oil contaminated soils were collected at Gbokoda in Warri North Local Government Area, Delta State, Nigeria. Mineral salt agar medium with these compositions per litre was prepared: $\mathrm{KH}_{2} \mathrm{PO}_{4}(1.3 \mathrm{~g}), \mathrm{Na}_{2} \mathrm{HPO}_{4}(2.13 \mathrm{~g})$, 
$\mathrm{NH}_{4} \mathrm{Cl}(0.5 \mathrm{~g}), \mathrm{MgSO}_{4} \cdot 7 \mathrm{H}_{2} \mathrm{O}(0.2 \mathrm{~g})$, and agar $(15.0$

g) (Kastner et al., 1998). This medium was used for the isolation of hydrocarbon utilizing bacteria. The bacterial isolates obtained were purified by subculturing on nutrient agar slant and kept in a refrigerator until it is needed for further studies (Fawole and Oso, 2007).

\section{Identification of Bacterial Isolates}

The genomic DNA of the bacterial cultures was isolated; the 16S rRNA gene was amplified by Polymerase Chain Reaction (PCR) using suitable primers. The PCR product obtained was purified using BigDye ${ }^{\mathrm{R}}$ PCR purification kit; and sequencing was done using applied Biosystem $\mathrm{CEQ}^{\mathrm{TM}}$ 2000x DNA Analysis System (Tanase et al., 2009).

\section{Standardization of Bacterial Inoculum}

Young culture of each bacterium (18 hours old culture) was standardized using 0.5 Mac Farland standard before being used to inoculate the mineral salt broth medium (Ilori and Amund, 2000).

\section{Preparation of Mixed Bacterial Culture Inocula}

The inocula used for the bacterial mixed culture medium were prepared as follow: CB1 contains 2 $\mathrm{ml}$ each of the standardized culture of Pseudomonas putida, Pseudomonas aeruginosa, Pseudomonas fluorescens, Bacillus subtilis, and Micrococcus luteus; CB2 contains $4 \mathrm{ml}$ each of standardized culture of Psendomonas putida, Pseudomonas aeruginosa and Pseudomonas fluorescens; CB3 contains $4 \mathrm{ml}$ each of standardized culture of Pseudomonas aeruginosa, Bacillus subtilis and Micrococcus luteus; CB4 contains $5 \mathrm{ml}$ each of standardized culture of Pseudomonas aeruginosa and Pseudomonas fluorescens; and CB5 contains $5 \mathrm{ml}$ each of standardized culture of Bacillus subtilis and Micrococcusluteus.

\section{Inoculation of Mineral Salt Medium with Consortia of Bacteria}

A set of six Erlenmeyer flasks labeled: CB1, CB2, $\mathrm{CB} 3, \mathrm{CB} 4, \mathrm{CB} 5$ and $\mathrm{CB} 6$ (control) were prepared each containing $400 \mathrm{ml}$ of sterile mineral salt broth medium supplemented with $1 \%$ crude oil. Ten milliliter $(10 \mathrm{ml})$ of the consortia was inoculated into separate flask. The sixth uninoculated flask served as a control (Ilori and Amund, 2000).

The content in the flasks were thoroughly mixed and incubated for 28 days at ambient temperature $\left(28 \pm 2{ }^{\circ} \mathrm{C}\right)$. The set up was placed on a shaker at $300 \mathrm{rpm}$ for aeration and samples were taken during biodegradation at intervals of four days to determine $\mathrm{pH}$, bacterial counts, and residual crude oil contents.

\section{Determination of Bacterial Load during Biodegradative Study}

At intervals of 4 days, $1 \mathrm{ml}$ of aliquot was taken from each of the set up and serially diluted in order to determine the bacterial population as the biodegradative study progressed. The analysis was done using pour plate technique and nutrient agar for the bacterial isolation and enumeration.

\section{Determination of $\mathrm{pH}$ of Mineral Salt Broth Medium during Biodegradative Study}

The $\mathrm{pH}$ value of each of the culture medium was measured with a $\mathrm{pH}$ meter (Clida) at 4 days intervals starting from day zero till the $28^{\text {th }}$ day. The $\mathrm{pH}$ meter was standardized before use (Boboye et al., 2010).

\section{Estimation of Crude Oil Concentration during Degradation}

Residual oil was extracted by liquid-liquid extraction method as described by Adebusoye et al. (2007). At intervals of 4 days, $20 \mathrm{ml}$ of the broth was taken for the extraction of residual crude oil. Evidence of degradation was then taken as the continuous decrease in the extracted residual crude oil with time from day zero (Ekpo and Udofia 2008; Panda et al., 2013).

\section{Statistical Analysis}

Means of the data obtained were determined using Statistical Package for Social Sciences (SPSS) version 15.0. The means were separated using ANOVA with Duncan Multiple Range Test (SPSS, 2010). 


\section{RESULTS}

Growth of Mixed Bacterial Culture in Crude Oil Amended Medium

The viable counts of the selected degrading mixed bacterial isolates $\mathrm{CB} 1, \mathrm{CB} 2, \mathrm{CB} 3, \mathrm{CB} 4$ and $\mathrm{CB} 5$ are as presented in figures $1-5$. A general increase in the viable counts of each of the degrading mixed bacterial culture was observed as the duration of biodegradative study progressed. Between day 0 and day 12 there were no significant differences in the viable counts of the different bacterial mixed cultures. Thereafter, there was increase in the viable bacterial counts which attained its peak on day 20 and dropped progressively till day 28 .

\section{Changes in $\mathrm{pH}$ of Mixed Bacterial Culture Medium during Crude Oil Degradation}

The changes in $\mathrm{pH}$ of the culture medium during crude oil degradation are presented in figure 6. In general, gradual decrease in the $\mathrm{pH}$ values of the culture medium was observed as the duration of the biodegradative study progressed. The $\mathrm{pH}$ value of the broth culture medium was 6.50 on day zero and it fell as the biodegradative study proceeded. The lowest $\mathrm{pH}$ value $(3.05 \pm 0.05)$ was observed in the culture medium CB1 containing
Pseudomonas aeruginosa, Pseudomonas putida, Pseudomonas fluorescens, Bacillus subtilis and Micrococcus luteus; followed by CB2 containing Psendomonas aeruginosa, Psendomonas putida

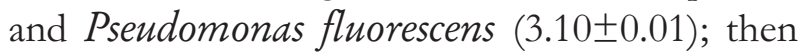
CB3 containing Pseudomonas aeruginosa, Bacillus subtilis and Micrococcus luteus (3.12 \pm 0.02$)$; then CB4 containing Pseudomonas aeruginosa and Pseudomonas fluorescens (3.13 \pm 0.01$)$; and finally CB5, Bacillus subtilis and Micrococcus luteus (3.88 \pm 0.02$)$ on day 28. There was statistical difference in the $\mathrm{pH}$ of the broth medium containing the consortia throughout the duration of the biodegradative study. However, the variation in the $\mathrm{pH}$ of the control (CB6) was not significantly different.

\section{Residual Crude Oil Contents during Biodegrative Study}

Degradation of crude oil by mixed bacterial isolates with time is presented in figure 7 . The amount of crude oil in each of the culture medium containing $\mathrm{CB} 1, \mathrm{CB} 2, \mathrm{CB} 3, \mathrm{CB} 4$, and CB5 decreased with time as the duration of degradation progressed.

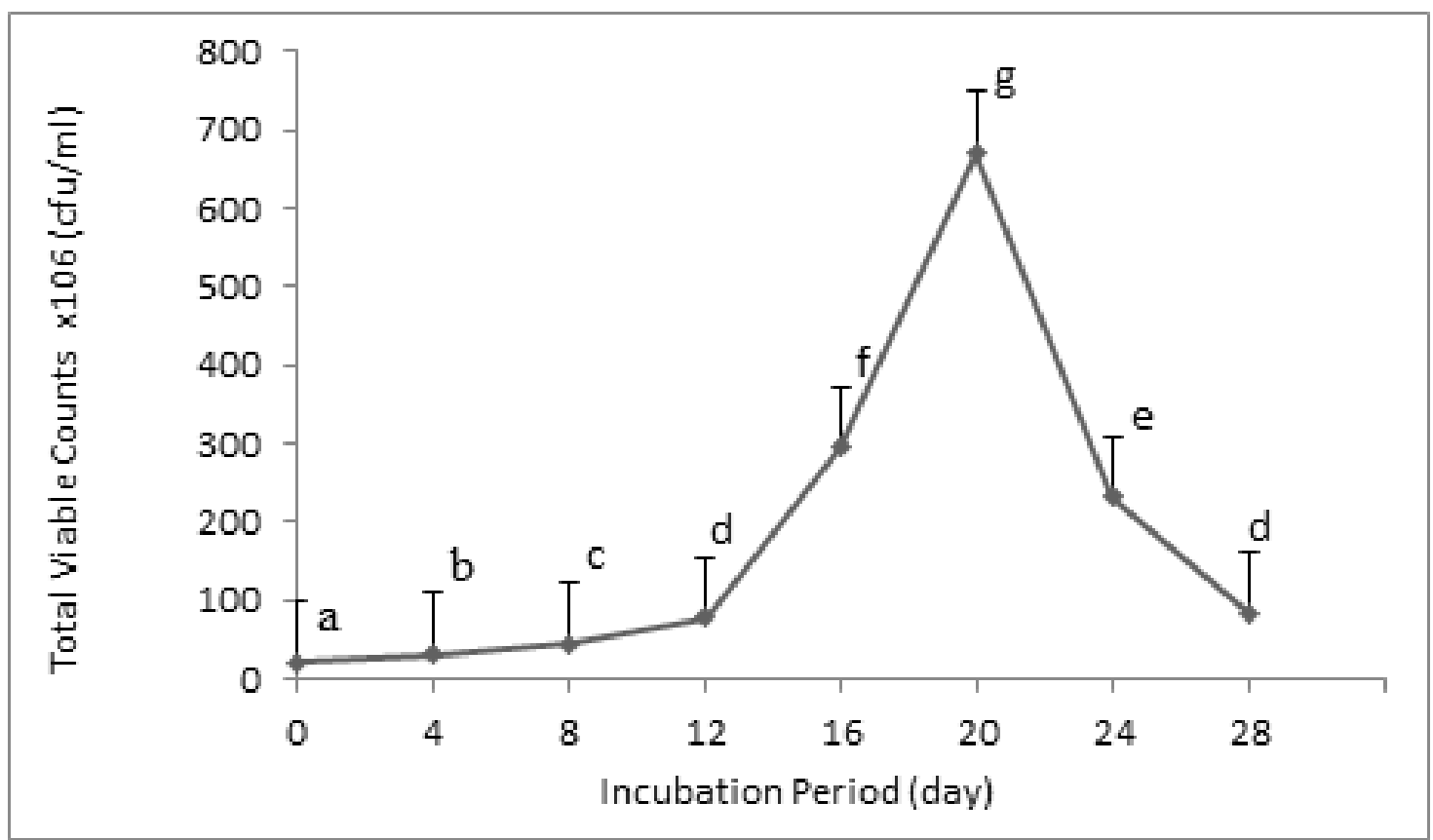

Figure 1: Growth of Mixed Bacterial Cultures (CB1) in Crude Oil Amended Medium

Data are means of three replicates \pm SDM.

Values followed by the same letters are not significantly different.

Cb1= Pseudomonas aeruginosa, Pseudomonas putida, Pseudomonasfluorescens, Bacillus subtilis and Micrococcus luteus 
Tomilayo et al.: Potentials of Mixed Cultures of Bacteria in the Biodegradation of Crude Oil

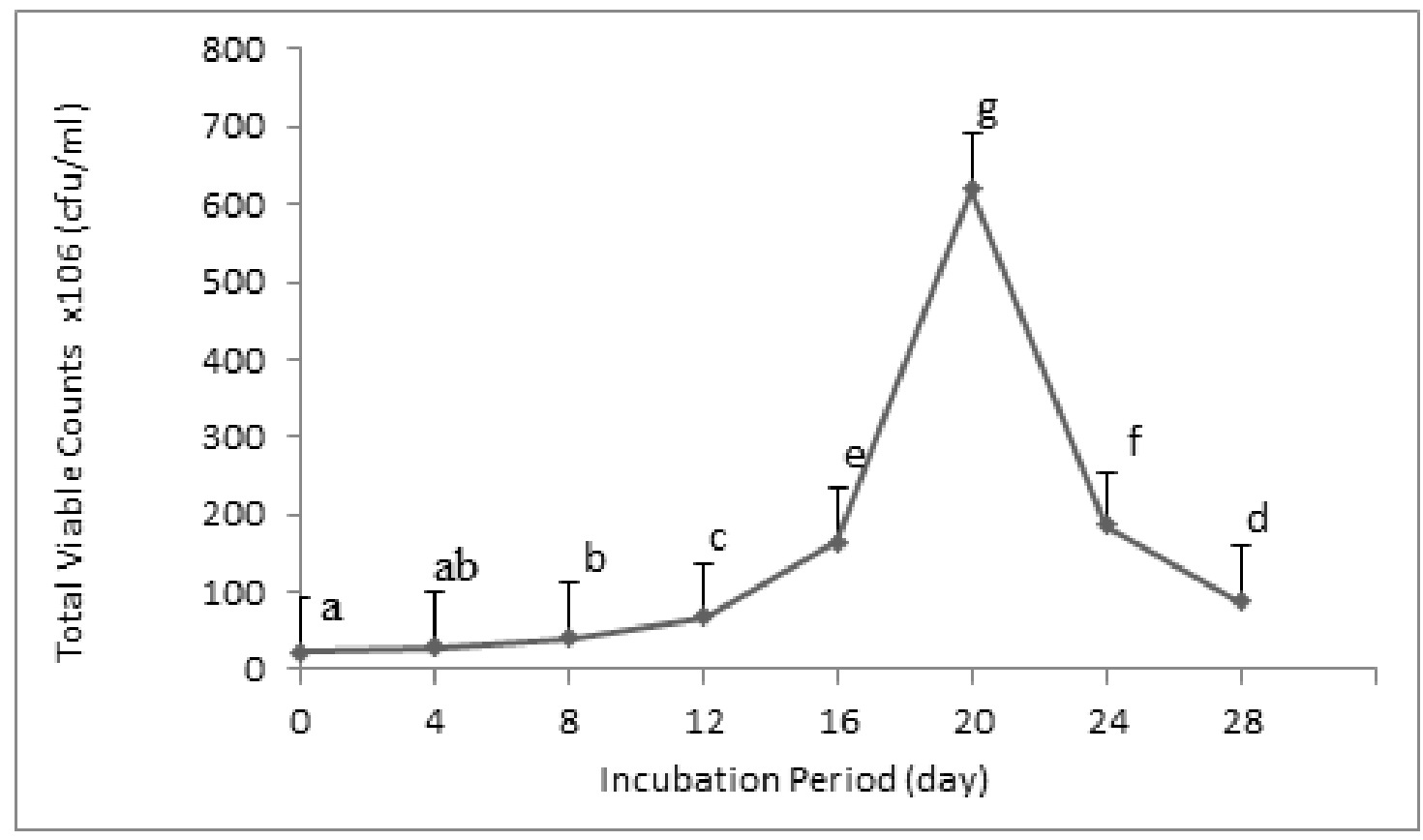

Figure 2: Growth of Mixed Bacterial Cultures (CB2) in Crude Oil Amended Medium

Data are means of three replicates \pm SDM.

Values followed by the same letters are not significantly different.

$\mathrm{Cb} 2=$ Pseudomonas aeruginosa, Pseudomonas putida and Pseudomonas fluorescens.

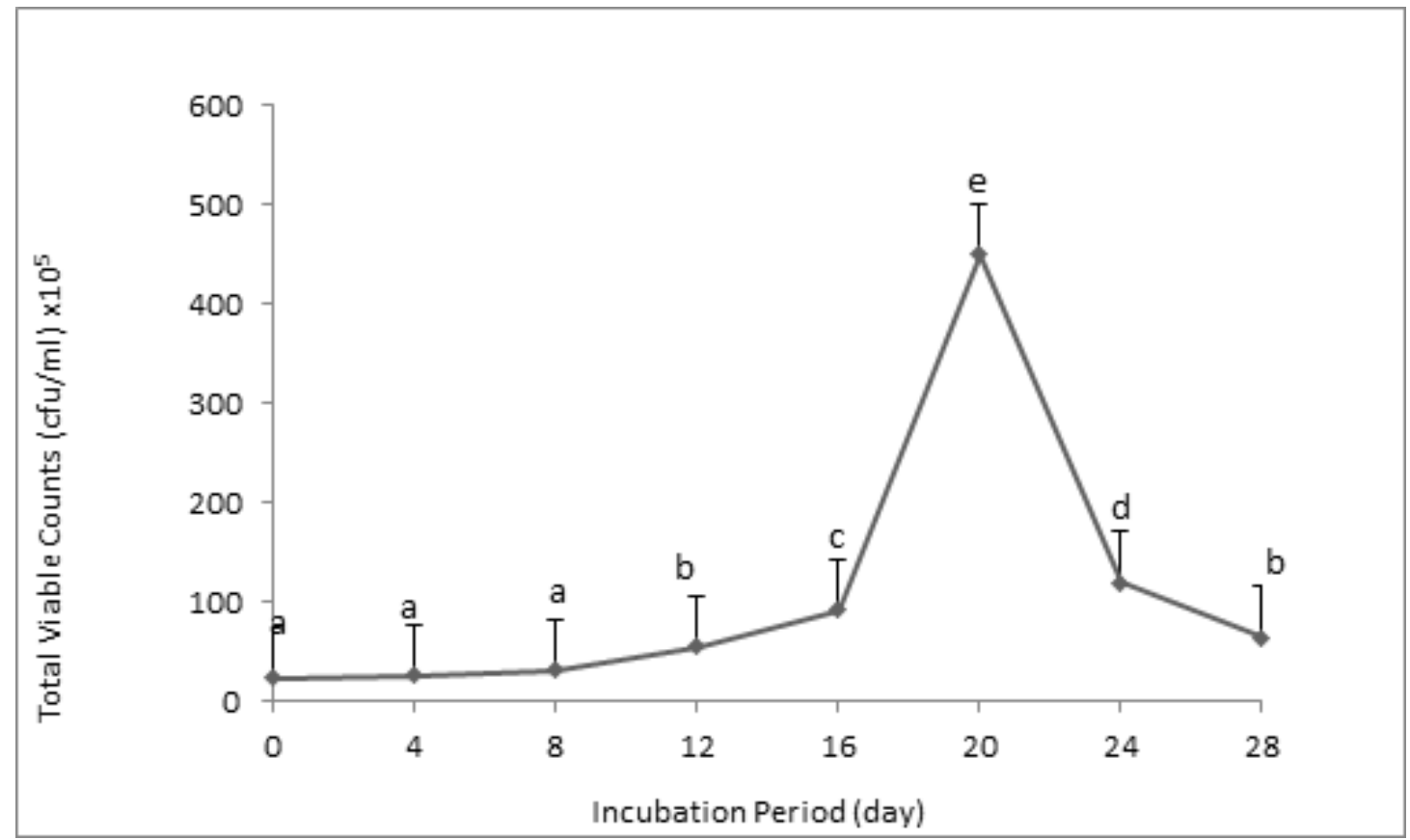

Figure 3: Growth of Mixed Bacteria Cultures (CB3) in Crude Oil Amended Medium

Data are means of three replicates \pm SDM.

Values followed by the same letters are not significantly different.

Cb3 $=$ Pseudomonas aeruginosa, Bacillus subtilis and Micrococcus luteus. 
Tomilayo et al.: Potentials of Mixed Cultures of Bacteria in the Biodegradation of Crude Oil

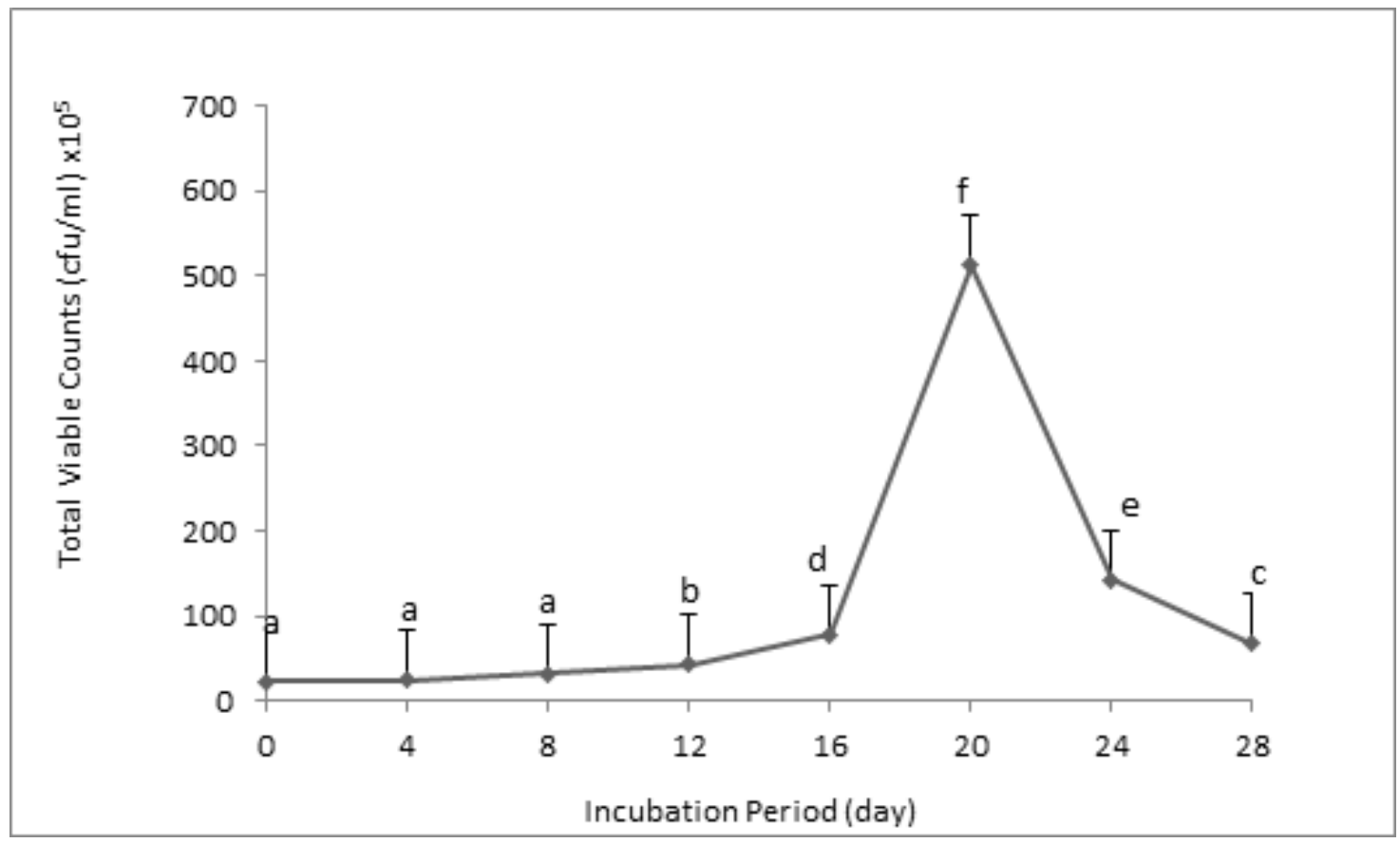

Figure 4: Growth of Mixed Bacterial Cultures (CB4) in Crude Oil Amended Medium

Data are means of three replicates \pm SDM.

Values followed by the same letter are not significantly different.

Cb4 = Pseudomonas aeruginosa and Pseudomonas fluorescens.

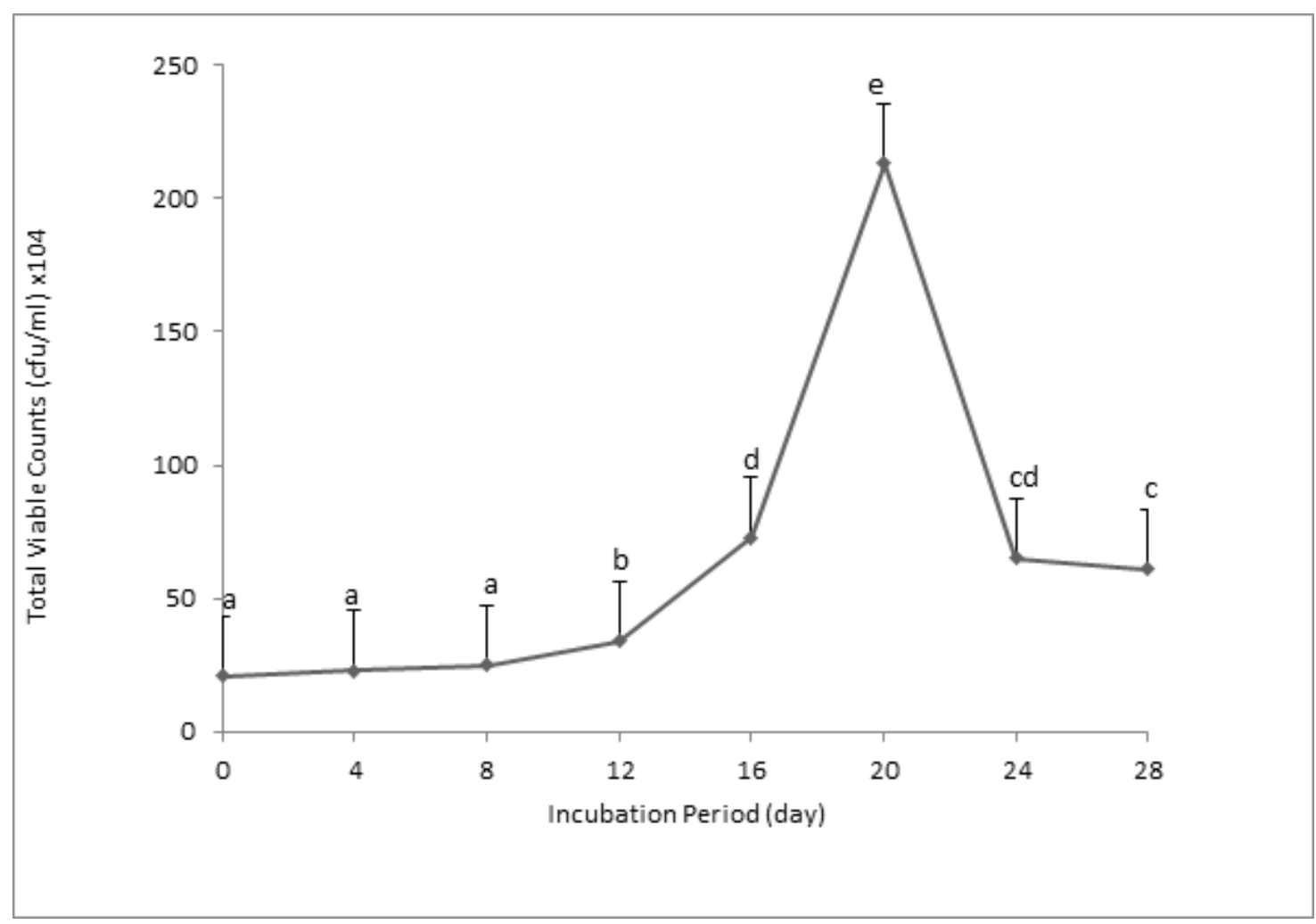

Figure 5: Growth of Mixed Bacterial Cultures (CB5) in Crude Oil Amended Medium

Data are means of three replicates \pm SDM.

Values followed by the same letters are not significantly different.

Cb5 = Bacillus subtilis and Micrococcus luteus. 


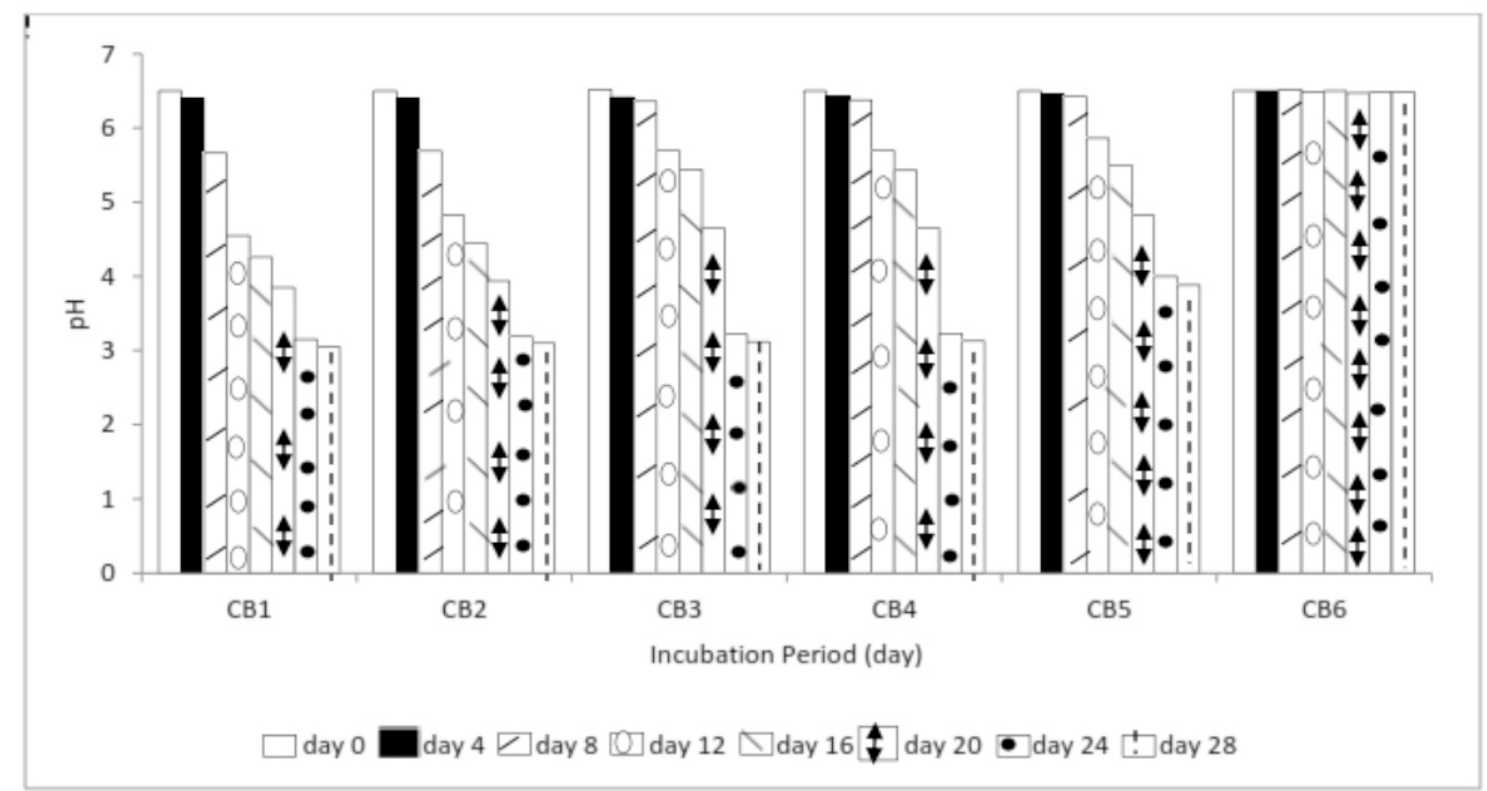

Figure 6: Changes in pH of Mixed Bacterial Culture Medium during Crude Oil Degradation

Data are means of three replicates \pm SDM.

Key: CB1 = Pseudomonas aernginosa, Pseudomonasputida, psendomonasfluorescens,

Bacillus subtilis and Micrococcus luteus; $\mathrm{CB} 2=$ Pseudomonas aeruginosa, Pseudomonas putida, psendomonas fluorescens; $\mathrm{CB} 3=$ Pseudomonas aeruginosa, Bacillus subtilis and Micrococcus luteus; $\mathrm{CB} 4=$ Pseudomonas aeruginosa and pseudomonasfluorescens CB5 = Bacillus subtilis and Micrococcus luteus; $\mathrm{CB} 6=$ Control (Mineral salt broth medium only)

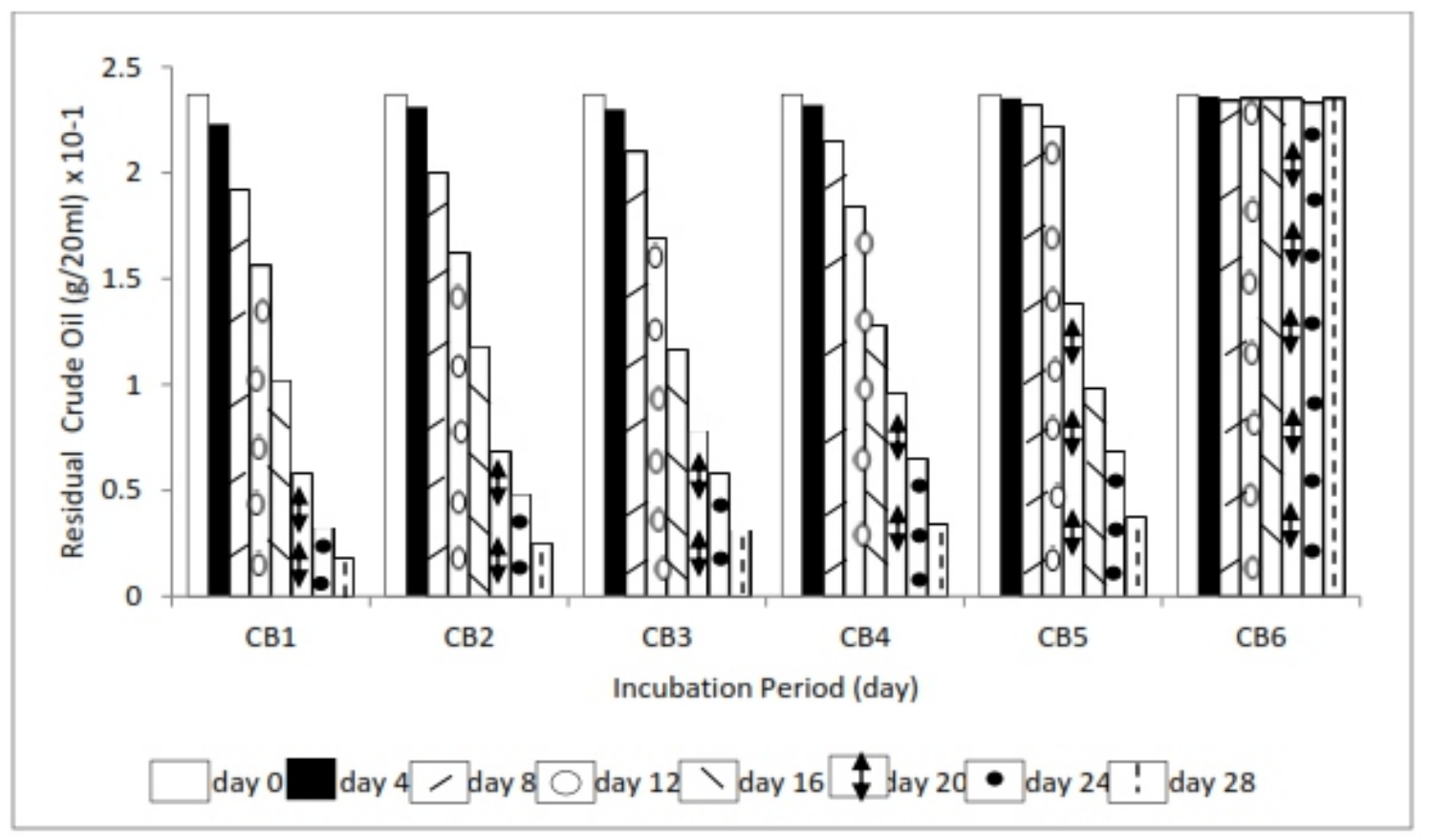

Figure 7: Residual Crude Oil Contents during Biodegradation

Data are means of three replicates \pm SDM.

Key: CB1= Pseudomonas aeruginosa, Pseudomonasputida, pseudomonasfluorescens,

Bacillus subtilis and Micrococcus luteus; CB2 = Pseudomonas aeruginosa, Pseudomonas putida, pseudomonas fluorescens; CB3 = Pseudomonas aeruginosa, Bacillus subtilis and Micrococcus luteus; $\mathrm{CB} 4=$ Pseudomonas aeruginosa and pseudomonasfluorescens; CB5 = Bacillus subtilis and Micrococcus luteus; CB6 = Control (Mineral salt broth medium only) 


\section{DISCUSSION}

This study revealed that the consortia of the degrading bacteria showed different abilities in the breaking down and utilization of the crude oil. The utilization of the crude oil as sole carbon and energy source by these cultures resulted in the progressive and significant increase in their viable counts. There was continuous reduction in the residual crude oil contents of each of the culture medium during the biodegradative study. This pattern of result is similar to the findings of Oboh et al. (2006); Akoachere et al. (2008); and Sebiotimo et al. (2010). The addition of crude oil to the mineral salt medium might perhaps create favourable condition for the growth of carbonoplastic bacteria. The reduction in the population of the hydrocarbon degrading bacteria from day twenty might perhaps be due to decreasing level in the residual crude oil contents. The continuous reduction in the available nutrient could possibly result to competition which in turn might lead to death of some cells. The mineralization of crude oil could lead to the production of toxic metabolites which might inhibit multiplication of cells. This includes the generation of $\mathrm{CO}_{2}$ during aerobic respiration and metabolism of the crude oil (Shekhar et al., 2015).

In a related study, Amadi and Odu (2003) reported an initial gradual increase in bacterial population which later decline as the biodegradation progressed. A similar trend was observed in this present study. The concomitant decrease in $\mathrm{pH}$ with crude oil degradation might not be unconnected with the fact that degradation of hydrocarbon compounds, usually leads to the production of organic acids that invariably leads to lowering of $\mathrm{pH}$ (Adebusoye et al., 2007; Osuji and Nwoye, 2007). The bacterial consortia were able to degrade the crude oil to different extent.

In this study, the consortium CB1 showed the highest degrading activity than others. CB1 was able to achieve $92.4 \%$ biodegradation of crude oil at day 28 of the commencement of biodegradative study. This was followed by CB2 $(89.5 \%)$, CB3 $(86.9 \%)$, CB4 (85.7\%), and lastly CB5 $(84.4 \%)$. In the control (CB6), the decrease in residual crude oil was $0.8 \%$ on day 28 . This value is significantly different from the range of
$84.4-92.4 \%$ achieved in the consortia. Similar to these results are the findings of Rahman et al. (2002) and Muthuswamy et al. (2008) who reported the ability of mixed bacterial consortia to degrade 28 to $51 \%$ of saturated hydrocarbon; and 0 to $18 \%$ of aromatic hydrocarbons present in crude oil.

Mixed populations with overall broad enzymatic capacities are required to degrade complex mixtures of hydrocarbons such as crude oil or diesel fuel. Such mixed cultures display metabolic versatility and superiority to pure cultures (Hamme et al., 2000). Furthermore, microorganisms not directly involved in the degradation process might probably play a role of producing micronutrients or surface-active agents for the solubilization of aromatic hydrocarbons (Ozaki et al., 2007).

The effectiveness of mixed culture (CB1) in biodegradation might probably be due to the fact that different microorganisms have capability of degrading different fractions of the hydrocarbons and thus when a consortium of these microbes is applied, the total degradation proved to be more effective. The effectiveness of mixed cultures in degradation could possibly be attributed to the fact that, some species utilize intermediates of degradation of the original hydrocarbon produced by other members of the culture, thus resulting to an effective degradation of the crude oil. Deppe et al. (2005) reported that an arctic microbial consortium was able to degrade $71 \%$ and $77 \%$ of crude oil from two different sources.

Ability to isolate high numbers of certain oil degrading microorganisms from an environment is commonly taken as evidence that those microorganisms are the active degraders in that environment. Hence, these consortia can be used to clean up oil spills in our environment.

\section{O N C L U S I O N RECOMMENDATION}

A N D

The results obtained in this study revealed the predominance of crude oil-degrading bacteria from crude oil polluted sites and confirmed them as resident microbes, which can be exploited in oil spill clean-up. Thus, the mixed cultures of 
Pseudomonas aeruginosa, Pseudomonas putida, Pseudomonas fluorescens, Bacillus subtilis, and Micrococcus luteus could be employed for effective and efficient bioremediation of the crude oil contaminated soils.

\section{REFERENCES}

Adebusoye, S. A., Ilori, M. O., Amund O. O., Teniola, O. D. and Olatope S. O. (2007). Microbial degradation of petroleum hydrocarbons in a polluted tropical stream. World Journal for Microbiology and Biotechnology, 23:1149-1159.

Akoachere, J. T. K., Akenji, T. N., Yongabi F. N., Nkwelang G. and Ndip R. N. (2008). Lubricating oil degrading bacteria in soils from filling stations and auto-mechanic Workshops in Buea, Cameroon: occurrence and characteristics of isolates. African Journal of Biotechnology, 7: 1700 $-1706$.

Akpotor E. (2019). Crude oil exploration and exploitation in Niger Delta: A Christian Concern. International Journal of Innovative Development and Policy Studies 7(2): $38-49$

Amadi, A. and Odu, C. T. I. (2003).Effect of simulated chemical demulsifier Contamination of $\quad \mathrm{s}$ o i l o $\mathrm{n}$ Carbondioxide evaluation and shift in microbial population in a fresh water mangrove ecosystem. International Journal of Biochemphysics, 2(1-2): 97-99

Bauer, J. E. and Capone, D. G. (1988).Effects of co-occuring aromatic hydrocarbons on degradation of individual polycyclic aromatic hydrocarbons. Applied and Environmental Microbiology, 54: 1649 1655.

Boboye, B., Olukunle, O. F. and Adetuyi, F. C. (2010).Degradative activity of bacteria isolated from hydrocarbon-polluted site in Ilaje, Ondo State, Nigeria. African Journal of Microbiology Research, 4: 2484 $-2491$.

Deppe, U., Richnow, H. H., Michaelis, W. and Antranikian, G. (2005).Degradation of crude oil by an Arctic Microbial Consortium. Extremophiles, 9: 461 - 470.
Ekpo, M. A. and Udofia, U. S. (2008). Rate of biodegradation of crude oil by microorganisms isolated from oil sludge environment. African Journal of Biotechnology, 7(24): 4495-4499.

Fawole, M. O. and Oso, B. A. (2007). Laboratory manual of microbiology. Spectrum book Limited Ibadan, Nigeria.123pp.

Hamme, J. D., Odumeru, J. A., and Ward, O. P. (2000).Community dynamics of a mixed bacterial culture growing on petroleum hydrocarbons in batch culture. Canadian Journal of Microbiology, 46: 441 - 450.

Ilori, M. O. N. and Amund, D. I. (2000). Degradation of Anthracene by bacteria isolated from oil polluted tropical soils. Zoological Nature for School, 55: 890 897.

Johnson, K., Anderson, S. and Jacobson, C. S. (1996). Phenotypic and genotypic characterisation of phenanthrenedegrading fluorescent Pseudomonas biovars. Applied Environmental Microbiology, 62:3815- 3825.

Kastner, M., Breuer- Jammli M. and MahroB., (1998).Impact of inoculation protocols, salinity, and $\mathrm{pH}$ on the degradation of Polycyclic Aromatic Hydrocarbons (PAHs) and survival of PAH degrading bacteria introduced into soil. Applied Environmental Microbiology, 64(1): 359 $-362$.

Mishra, S., Jyoti, J., Kuhad, R.C. and Lal, B. (2001). Evaluation of inoculum addition to stimulate in situ bioremediation potential of an oily-sludge contaminated soil. Applied Environmental Microbiology, 67(4): 1675 - 1681.

Muthuswamy, S., Arthur, R. B., Sang-Ho, B. and Sel-Eok, Y. (2008). Biodegradation of crude oil by individual bacterial strains and a mixed bacterial consortium isolated from hydrocarbon contaminated areas. Research Article, 36(1): 92 - 96.

Oboh, O. B., Ilori, O. M., Akinyemi, O. J. and Adebusoye, A. S. (2006). Hydrocarbon degrading potentials of bacteria isolated from a Nigerian Bitumen (Tarsland) deposit. Nature Science, 4(3): 51 - 57.

Ohanmu E. O., Bako S. P., Ohanmu E., and Osaretin O. (2019). Environmental implications, properties and attributes of crude oil in the oil producing States of 
Nigeria. Ecologia 9: 1 -9

Okerentugba, P. O. and Ezenronye, O. U. (2003). Petroleum degrading potentials of single and mixed microbial cultures isolated from rivers and refinery effluent in Nigeria. African Journal of Biotechnology, 2: 288 - 292.

Osuji, L. C. and Nwoye, I. (2007). An appraisal of the impact of petroleum hydrocarbons on soil fertility: the Owaza experience. African Journal of Agricultural Research, 2(7): $318-324$.

Ozaki, S., Kishimoto, N. and Fujita, T. (2007). Change in the predominant bacteria in a microbial consortium cultured on media containing aromatic and saturated hydrocarbons as the sole carbon source. Microbes and Environments, 22: 128 135.

Panda, S. K., Kar, R. N. and Panda, C. R. (2013). Isolation and identification of petroleum hydrocarbon degrading microorganisms from oil contaminated environment. International Journal of Environmental Science, 3(5): $1314-1320$.

Rahman, K. S. M., Thahira-Rahman, J., Thay u m a van, T. a n d Lakshmanaperumalsamy, P. (2002).Towards efficient crude oil degradation by a mixed bacterial consortium. Bioresource Technology,
85(3): $257-261$.

Sebiotimo, A., Bankole, S. A. and Awosanya, A. O. (2010). Determination of the ability of microorganisms isolated from mechanic soil to utilise lubricating oil as carbon source. American Journal of Microbiological Research, 4(21): 2257 2264

SPSS (2010). Statistical Package for Social Scientists, version 15.0 for window evaluation.www.spss.com

Shekhar S.K., Godheja J., and Modi D.R. (2015). Hydrocarbon bioremediation efficiency by five indigenous bacterial strains isolated from contaminated soils. British Journal of Environmental Sciences, 3(4): $27-39$

Tanase, A. M., Trasca C., Vassu, T. Olteanu, A., Pelinescu D., Csutak O., Ionescu R., and Stoica I. (2009). Phylogenetic analysis on 16S ribosomal DNA of Pseudomonas strains from oil polluted soil. Roman Biotechnological Letter, 14(6): 4779 4785.

Ujowundu, C. O., Kalu, F. N., Nwaoguikpe R. N., Kalu, O. I., Ihejirika, C. E., Nwosunjoku, E. C. and Okechukwu, R. I. (2011). Biochemical and physical characterization of diesel petroleum contaminated soil in Southeastern Nigeria. Research Journal of Chemical Science, 1(8): 57-62 